\title{
Implementasi Program Kredit Usaha Pembibitan Sapi (KUPS) di Kabupaten Sragen
}

\author{
Dwiningtyas Padmaningrum \\ Program Studi Agribisnis, Fakultas Pertanian, Universitas Sebelas Maret \\ Jl. Ir. Sutami No 36A Surakarta 57126 \\ Email:arum_fpuns@yahoo.com
}

\begin{abstract}
ABSTRAK
Penelitian ini mengkaji implementasi dan kendala program Kredit Usaha Pembibitan Sapi (KUPS) di Kabupaten Sragen. Penelitian menggunakan metode pendekatan kualitatif deskriptif, dimana data mengenai implementasi dan kendala program KUPS dikumpulkan melalui wawancara terhadap informan serta dokumen. Informan ditetapkan secara purposive mewakili semua stakeholder dalam program KUPS, yakni dari unsur kelompok/gabungan kelompok peternak selaku pelaku usaha pembibitan sapi, unsur lembaga perbankan serta unsur Dinas Peternakan dan Perikanan Kabupaten Sragen. Program KUPS untuk kelompok/gabungan kelompok peternak belum dapat diimplementasikan secara penuh karena beberapa kendala teknis dan ekonomis. Kendala teknis antara lain kurangnya kemampuan teknis dan manajemen, tidak ada perusahaan bibit/koperasi sebagai mitra, kesulitan pengadaan bibit sapi yang berkualitas serta tidak ada pendampingan. Kendala ekonomis meliputi fluktuasi harga pasar, kemampuan angsuran kredit, jangka waktu kredit pendek, resiko kegagalan inseminasi buatan dan kematian sapi. Untuk meningkatkan partisipasi dan keberhasilan KUPS, perlu adanya realisasi kemitraan dengan perusahaan bibit sapi yang bertanggung jawab dalam pendampingan teknis dan manajemen serta melibatkan pihak dinas terkait, perbankan maupun mitra dalam pendampingan dan monitoring.
\end{abstract}

Kata kunci: program KUPS, pembibitan, sapi, kelompok peternak

\section{Implementation of Cattle Breeding Loan Program in Sragen}

\begin{abstract}
The study examined the implementation and constraints of Cattle Breeding Loan Program (KUPS) in Sragen. The study used a descriptive qualitative approach, where data on program implementation and constraints were collected through interviews with informants and documents. Informants were stipulated purposively, which represent the entire stakeholders, i.e. from element of farmer group/combined groups of cattle breeder, element banking institutes as well as the government element. The KUPS program for groups/combined groups of breeder could not yet be fully implemented due to several technical and economical constraints. Technical constraints included lack of technical skills and management, there was no breeding companies/cooperatives as partner, difficulty in finding good quality of cattle and lack of assistance. Economic constraints included fluctuations in market prices, payment of the credit, short credit period, and risk of failure of artificial insemination and animal deaths. To increase participation and successfulness this program, it is needed the realization of a partnership with breeding companies, technical and management assistances which involve the stakeholders, banks and partners in the mentoring and monitoring.
\end{abstract}

Key words: KUPS program, breeding, cattle, farmer group 


\section{PENDAHULUAN}

Sub sektor peternakan merupakan sub sektor strategis dalam upaya pemenuhan kebutuhan pangan, disamping sebagai mata pencaharian sebagian besar masyarakat pedesaan. Namun demikian, usaha peternakan khususnya sapi potong sampai saat ini masih menghadapi banyak kendala, antara lain produktivitas masih rendah yang ditunjukkan dari jarak beranak (calving interval) lebih dari 21 bulan, perkawinan (service/conseption) lebih dari 3 kali, angka kematian anak sapi tinggi, pemotongan sapi betina produktif serta kuantitas pakan yang rendah (Dirjen Budidaya Ternak Ruminansia dalam Badan Penelitian dan Pengembangan Pertanian, 2010). Hal ini mengakibatkan pengembangan populasi sapi potong menjadi lambat dibandingkan dengan pertambahan jumlah penduduk Indonesia, sehingga impor sapi dan daging cukup tinggi. Pasokan daging sapi dalam negeri untuk kebutuhan konsumsi baru mencapai sekitar 60\%, karena itu dalam rangka pemenuhan kebutuhan daging dan susu dalam negeri diperlukan peningkatan produksi melalui penambahan jumlah bibit sapi (Dirjen Peternakan Departemen Pertanian, 2009).

Berangkat dari lambatnya usaha pembibitan sapi oleh peternak serta usaha pembibitan sapi tidak menarik kalangan pelaku usaha karena dianggap kurang menguntungkan dan memerlukan waktu lama, maka diluncurkan program Kredit Usaha Pembibitan Sapi (KUPS). Berdasarkan Peraturan Menteri Pertanian Nomor 40/Permentan/PD.400/9/2009 (Dirjen Peternakan Departemen Pertanian, 2009), indikator keberhasilan pelaksanaan usaha pembibitan sapi melalui KUPS antara lain: 1) peningkatan jumlah populasi sapi; 2) terbangunnya industri dan kelompok pembibitan sapi; 3) tersalurnya kredit; 4) terealisasinya angsuran kredit tepat waktu.

Meskipun demikian, menurut Kasubdit Pengembangan Bibit Ditjen Peternakan dan Kesehatan Hewan Kementerian Pertanian (www.bisnis-jatim.com), realisasi penyerapan KUPS secara nasional hingga Oktober tahun 2011 hanya Rp 391,5 miliar atau 10\% dari total plafon Rp 3,91 triliun sejak skim kredit tersebut diluncurkan tahun 2009. Lambannya penyerapan dana KUPS disebabkan belum banyak perusahaan pembibitan sapi yang menggeluti sektor tersebut. Di sisi lain, kalangan bank pelaksana KUPS belum memiliki database tentang kelompok-kelompok peternak maupun koperasi yang layak dibiayai dengan kredit program tersebut.

Rendahnya penyerapan skim kredit KUPS juga terjadi di Kabupaten Sragen, dimana sejak program diluncurkan, hanya ada 8 kelompok ternak yang memanfaatkan dengan total kredit tersalurkan Rp 1,5 milyar (Dinas Peternakan dan Perikanan Kabupaten Sragen, 2012). Hal ini kurang sesuai dengan harapan pemerintah daerah dalam mengembangkan kelompok peternak sebagai upaya peningkatan populasi sapi potong yang pada tahun 2011 berjumlah 113.566 ekor (Dinas Peternakan dan Perikanan Kabupaten Sragen, 2012).

Dalam teori difusi inovasi, Rogers (2003) mengemukakan bahwa inovasi akan lebih cepat diterima oleh individu apabila memiliki keuntungan relatif yang lebih tinggi, lebih kompatibel, memiliki tingkat triabilitas dan observabilitas tinggi serta tingkat kerumitan yang rendah. Apabila dilihat dari sudut pandang inovasi, banyak faktor yang mempengaruhi cepat dan lambatnya adopsi program KUPS sebagai suatu program baru oleh peternak. Mengacu pada pendapat Leeuwis (2006) apa yang dilakukan dan tidak dilakukan oleh peternak sebagian tergantung pada persepsi mereka tentang karakteristik program KUPS, persepsi serta evaluasi terhadap berbagai konsekuensi teknis maupun ekonomis dari keikutsertaan mereka.

Penelitian ini mengkaji implementasi dan kendala program KUPS di Kabupaten Sragen. Hasil penelitian diharapkan menjadi umpan balik sebagai mekanisme krusial dalam implementasi program serta menjadi kerangka evaluatif yang bisa dimanfaatkan sebagai masukan untuk perbaikan dalam aturan maupun pelaksanaan program KUPS. 


\section{MATERI DAN METODE}

Penelitian ini menggunakan pendekatan kualitatif deskriptif, dimana peneliti menekankan catatan dengan deskripsi kalimat yang rinci, lengkap dan mendalam untuk menggambarkan situasi sebenarnya guna mendukung penyajian data (Sutopo, 2006). Data yang digunakan meliputi data kuantitatif maupun kualitatif, yang dikumpulkan melalui wawancara dengan informan maupun dokumen. Dalam penelitian ini informan ditetapkan secara purposive, yakni dari unsur kelompok/ gabungan kelompok peternak peserta program KUPS mewakili pelaku usaha pembibitan sapi, unsur lembaga perbankan serta unsur Dinas Peternakan dan Perikanan Kabupaten Sragen.

\section{HASIL DAN PEMBAHASAN}

\section{Realisasi KUPS di Kabupaten Sragen}

Kredit Usaha Pembibitan Sapi (KUPS) adalah kredit yang diberikan bank pelaksana kepada pelaku usaha pembibitan sapi yang memperoleh subsidi bunga dari pemerintah. Manfaat pelaksanaan usaha pembibitan sapi menggunakan skim KUPS sesuai Peraturan Menteri Pertanian Nomor 40/Permentan/ PD.4000/9/2009 adalah: 1) tersedianya bibit sapi berkelanjutan bagi pelaku usaha pembibitan sapi; 2) berkembangnya usaha pembibitan sapi pola kemitraan; 3) terciptanya peluang usaha dan kesempatan kerja bagi masyarakat; 4) mempercepat upaya swasembada daging sapi; serta 5) menghasilkan daging, susu, energi berupa gas bio dan pupuk organik (Dirjen Peternakan Departemen Pertanian, 2009).

Berdasarkan Peraturan Menteri Keuangan Nomor 131/PMK.05/2009 (Dirjen Peternakan Departemen Pertanian, 2009), pelaku usaha pembibitan sapi yang bisa memanfaatkan skim kredit dari program KUPS adalah perusahaan pembibitan, koperasi serta kelompok/gabungan kelompok peternak yang melakukan usaha pembibitan sapi. Kebutuhan indikatif KUPS meliputi komponen biaya untuk pengadaan sapi, kandang/manajemen, pakan, obatobatan, inseminasi buatan, tenaga kerja serta nomor identifikasi (microchip). Pelaku usaha pembibitan sapi peserta program KUPS di Kabupaten Sragen, merupakan kelompok/ gabungan kelompok tani ternak yang merupakan sub bagian dari kelompok tani, dimana karakteristik realisasi KUPS tersaji pada Tabel 1.

Pelaku usaha pembibitan sapi secara administratif terdaftar sebagai kelompok tani dan bukan kelompok ternak, karena secara organisatoris kelompok tani ternak (kelompok ternak) tidak berdiri sebagai kelompok tersendiri, tetapi merupakan sub bagian dari kelompok tani. Kelompok tani pula yang tercatat pada Badan Pelaksana Penyuluhan Pertanian Kabupaten Sragen. Anggota sub kelompok tani ternak bukanlah murni seorang peternak, melainkan petani yang memiliki usaha sambilan ternak sapi. Konsekuensi negatif dari status peserta yang bukan peternak murni antara lain pengelolaan usaha pembibitan sapi tidak bisa optimal, karena alokasi waktu, tenaga dan dana terserap untuk usahatani lainnya. Konsekuensi positifnya, ada cabang usahatani yang saling melengkapi dan memberi penghasilan tambahan.

Dilihat dari persentase kelahiran anak sapi, angka kelahiran anak sapi rata-rata $34 \%$ per tahun, dimana dalam jangka 2 tahun (tahun 2010 sampai tahun 2012) total lahir 86 ekor anak sapi dari total pengadaan 126 ekor sapi induk. Hal ini juga mengindikasikan bahwa tingkat keberhasilan bunting dari sapi induk berkisar 34\%. Dari data ini, dan dikombinasikan dengan angka kematian induk sapi maupun anak sapi yang mencapai 7\% selama kurun waktu 2 tahun, dapat dipahami apabila peternak peserta KUPS mengalami kesulitan dalam mengembalikan kredit apabila hanya mengandalkan usaha pembibitan sapi melalui program KUPS.

Pendeknya jangka waktu pinjaman skim KUPS yang ditentukan oleh bank selama 2 tahun juga dirasa memberatkan peserta. Pola angsuran kredit program dalam 
Tabel 1. Realisasi KUPS tahun 2010 Kabupaten Sragen

\begin{tabular}{|c|c|c|c|c|c|c|c|}
\hline $\begin{array}{c}\text { Nama } \\
\text { Kelompok } \\
\text { Tani }\end{array}$ & $\begin{array}{c}\text { Desa } \\
\text { (Kecamatan) }\end{array}$ & $\begin{array}{l}\text { Jumlah } \\
\text { Pinjaman } \\
\text { (Rp) }\end{array}$ & $\begin{array}{c}\text { Jumlah } \\
\text { Ternak Awal } \\
\text { (ekor) }\end{array}$ & $\begin{array}{c}\text { Jumlah } \\
\text { Ternak } \\
\text { Lahir } \\
\text { (ekor) }\end{array}$ & $\begin{array}{c}\text { Jumlah } \\
\text { Ternak } \\
\text { Mati } \\
\text { (ekor) }\end{array}$ & $\begin{array}{l}\text { Jumlah } \\
\text { Ternak } \\
\text { Dijual } \\
\text { (ekor) }\end{array}$ & $\begin{array}{c}\text { Jumlah } \\
\text { Ternak } \\
\text { Saat Ini } \\
\text { (ekor) }\end{array}$ \\
\hline Ngudi Rahayu & $\begin{array}{l}\text { Pringanom } \\
\text { (Masaran) }\end{array}$ & 750.000 .000 & 60 & 43 & 3 & 30 & 70 \\
\hline $\begin{array}{l}\text { Sumber } \\
\text { Makmur }\end{array}$ & $\begin{array}{l}\text { Taraman } \\
\text { (Sidoharjo) }\end{array}$ & 95.000 .000 & 9 & 5 & - & 5 & 9 \\
\hline Ngudi Tani & $\begin{array}{l}\text { Gringging } \\
\text { (Sambungmacan) }\end{array}$ & 95.000 .000 & 8 & 5 & 2 & 3 & 8 \\
\hline Sumber Sewu & $\begin{array}{l}\text { Majenang } \\
\text { (Sukodono) }\end{array}$ & 95.000 .000 & 10 & 8 & 1 & 7 & 10 \\
\hline Maju Makmur & $\begin{array}{l}\text { Kleco } \\
\text { (Sidoharjo) }\end{array}$ & 95.000 .000 & 10 & 5 & 5 & 5 & 5 \\
\hline $\begin{array}{l}\text { Margo } \\
\text { Makmur }\end{array}$ & $\begin{array}{l}\text { Taraman } \\
\text { (Sidoharjo) }\end{array}$ & 95.000 .000 & 8 & 5 & - & 5 & 8 \\
\hline Sari Tani & $\begin{array}{l}\text { Kedawung } \\
\text { (Kedawung) }\end{array}$ & 65.000 .000 & 5 & 3 & 1 & 2 & 5 \\
\hline Tani Mulyo II & $\begin{array}{l}\text { Jetak } \\
\text { (Sidoharjo) }\end{array}$ & 210.000 .000 & 16 & 12 & 3 & 4 & 21 \\
\hline
\end{tabular}

Sumber : Dinas Peternakan dan Perikanan Kabupaten Sragen, 2012

bentuk angsuran pokok yang dibayar setiap tahun (2 kali angsuran lunas) dan angsuran bunga pinjaman yang dibayar setiap bulan dengan besaran $0,42 \%$ (atau $5 \%$ per tahun). Agunan yang digunakan untuk pengajuan pinjaman berupa sertifikat tanah hak milik anggota atau pengurus kelompok. Pengajuan skim kredit KUPS sendiri atas nama kelompok, yang kemudian didistribusikan kepada anggota. Skim kredit untuk setiap 1 ekor sapi adalah Rp 10 juta. Dengan asumsi biaya pemeliharaan Rp 14.000,- per hari, maka seekor sapi rata-rata membutuhkan biaya pemeliharaan sekitar Rp 5.040.000,per tahun dengan biaya IB Rp 150.000,(apabila 3 kali IB terjadi kebuntingan).

\section{Implementasi Program KUPS}

Program KUPS bisa berjalan baik apabila pelaksanaannya di lapangan mengacu pada standar yang sudah diterapkan. Dalam penelitian ini, indikator implementasi program KUPS dilihat dengan membandingkan masing-masing aspek KUPS dengan pelaksanaannya, seperti tersaji pada Tabel 2.

Dari Tabel 2 terlihat bahwa dari sisi oganisasi dan keaktifan kelompok peternak, secara organisatoris kelompok tani ternak sebagai bagian dari sub kelompok tani merupakan kelompok aktif dan terdaftar di Dinas Pertanian Kabupaten Sragen. Keaktifan kelompok antara lain dilihat dari penyelenggaraan pertemuan rutin dan kegiatan kelompok, sebagai contoh, kelompok tani ternak peserta KUPS sebelumnya pernah mengikuti program Kredit Ketahanan Pangan dan Energi (KKPE) untuk usaha penggemukan sapi. Selain memiliki pengurus dan anggota yang aktif, kelompok tani juga memiliki aturan yang disepakati anggota.

Persyaratan yang mewajibkan penerima KUPS adalah peternak diimplimentasikan dalam bentuk penetapan peserta program dari kalangan petani yang memiliki usaha ternak (petani ternak). Sebagaimana petani lain, peternak peserta KUPS tidak hanya mengandalkan pendapatan dari satu jenis usahatani saja, melainkan mengkombinasikan berbagai penanaman komoditas seperti padi dan palawija dengan peternakan seperti ayam, sapi ataupun kambing. Tiap jenis produksi yang berlainan didalam suatu usaha tani lazim disebut 'cabang usaha' (enterprise) (Mosher, 1991). Seorang petani tidak dapat 
Tabel 2. Perbandingan antara persyaratan dengan implementasi aspek KUPS

\begin{tabular}{|c|c|}
\hline Persyaratan & Implementasi \\
\hline $\begin{array}{l}\text { Kelompok/gabungan kelompok ternak } \\
\text { memiliki oganisasi dan pengurus yang aktif }\end{array}$ & $\begin{array}{l}\text { Kelompok ternak peserta KUPS adalah sub } \\
\text { kelompok tani ternak yang secara organisatoris } \\
\text { merupakan sub kelompok tani yang memiliki } \\
\text { organisasi dan pengurus yang aktif }\end{array}$ \\
\hline $\begin{array}{l}\text { Kelompok/gabungan kelompok ternak } \\
\text { memiliki anggota yang terdiri dari peternak }\end{array}$ & $\begin{array}{l}\text { Anggota kelompok ternak bukan peternak } \\
\text { murni, melainkan petani yang sekaligus } \\
\text { beternak sapi (peternakan rakyat) }\end{array}$ \\
\hline $\begin{array}{l}\text { Kelompok/gabungan kelompok ternak terdaftar } \\
\text { pada dinas kabupaten/kota setempat }\end{array}$ & $\begin{array}{l}\text { Sebagai sub bagian kelompok tani, otomatis } \\
\text { kelompok tani ternak terdaftar di Dinas } \\
\text { Pertanian maupun Dinas Peternakan dan } \\
\text { Perikanan }\end{array}$ \\
\hline $\begin{array}{l}\text { Kelompok/gabungan kelompok ternak } \\
\text { memiliki aturan kelompok/gabungan kelompok } \\
\text { yang disepakati anggota }\end{array}$ & $\begin{array}{l}\text { Kelompok tani ternak peserta KUPS secara } \\
\text { organisatoris merupakan sub kelompok tani } \\
\text { yang memiliki aturan yang disepakati anggota }\end{array}$ \\
\hline $\begin{array}{l}\text { Kelompok/gabungan kelompok ternak } \\
\text { memenuhi prosedur baku pelaksanaan produksi } \\
\text { bibit }\end{array}$ & $\begin{array}{l}\text { Peserta KUPS umumnya sudah berpengalaman } \\
\text { (terbiasa) memelihara sapi, tetapi belum } \\
\text { berpengalaman dalam produksi bibit sapi, } \\
\text { sehingga prosedur baku pelaksanaan produksi } \\
\text { bibit belum sepenuhnya dipenuhi }\end{array}$ \\
\hline $\begin{array}{l}\text { Kelompok/gabungan kelompok ternak bermitra } \\
\text { dengan perusahaan atau koperasi }\end{array}$ & Tidak ada mitra \\
\hline $\begin{array}{l}\text { Kelompok/gabungan kelompok } \\
\text { memperoleh rekomendasi dari } \\
\text { kabupaten/kota }\end{array}$ & $\begin{array}{l}\text { Ada rekomendasi dari Dinas Peternakan dan } \\
\text { Perikanan untuk memperoleh skim kredit dari } \\
\text { KUPS }\end{array}$ \\
\hline
\end{tabular}

Sumber : analisis hasil wawancara

begitu saja memilih cabang-cabang usaha taninya tanpa mempertimbangkan hubungan satu sama lain, tetapi kombinasi dari berbagai bidang usaha penuh dengan 'hasilhasil gabungan' (joint product) dan 'biayabiaya gabungan' (joint costs). Padi, yang ditanam untuk diambil gabahnya, juga bisa dimanfaatkan jeraminya sebagai pakan ternak. Kotoran ternak dapat dimanfaatkan sebagai pupuk, dan sebagian pupuk yang diberikan untuk tanaman padi.

Pendapatan yang diperoleh dari berbagai cabang usahatani ini, menjadi penolong peternak peserta program KUPS, karena usaha pembibitan sapi tidak bisa dipetik hasilnya dalam jangka pendek, sehingga angsuran kredit berupa bunga yang dibayar setiap bulan, diambil dari hasil usahatani lain, bukan dari pembibitan ternak. Untuk angsuran pinjaman pokok yang dibayar setiap tahun, rata-rata peserta KUPS mengambil dana dari penjualan anak sapi/pedet, bahkan menjual induk sapi yang seharusnya tidak diperbolehkan. Dari hasil wawancara, banyak peserta KUPS yang menjual induk sapi program KUPS untuk melunasi kredit, selain itu peserta juga ada yang menjual induk sapi dan menukarnya dengan induk baru karena sapi tidak bunting melalui proses inseminasi buatan (IB) lebih dari 3 - 4 kali, dengan biaya per pelaksanaan IB berkisar Rp 50.000,-.

Praktek penjualan induk sapi program KUPS ini bisa dilakukan karena induk sapi dari program KUPS tidak dipasang microchip sesuai Surat Edaran Dirjen Peternakan Nomor 12020/SE/KU.340/F/ 03/2010 (Dirjen Peternakan Departemen Pertanian, 2010), yang mewajibkan pemasangan microchip dalam bentuk ear 
tag. Ear tag seharusnya dipasang pada telinga sapi bagian kanan/kiri, dan dipasang paling lambat 3 bulan setelah realisasi ternak. Tidak adanya pemasangan microchip dilandasi beberapa alasan, yakni tidak adanya pihak yang menyediakan microchip dan dari pihak peternak sendiri banyak yang enggan kalau sapi mereka dipasang microchip karena sapi tidak bisa dijual dengan mudah (bisa dideteksi keberadaannya). Pemasangan microchip antara lain dilakukan sebagai monitoring terhadap sapi KUPS secara berkala, selain menjaga agar tidak terjadi inbreeding.

Apabila dilihat dari kemampuan kelompok ternak untuk memenuhi prosedur baku pelaksanaan produksi bibit sapi, secara realita belum diimplimentasikan secara penuh. Sebagai petani yang sekaligus beternak sapi, peserta KUPS umumnya sudah berpengalaman (terbiasa) memelihara sapi, sehingga dianggap sudah memenuhi prosedur baku pelaksanaan produksi bibit, padahal mereka secara khusus belum memiliki pengalaman dalam produksi bibit sapi ras. Pengusahaan ternak selama ini masih berdasarkan 'kebiasaan', yakni pola tindakan peternak sehari-hari. Kebiasaan tersebut bisa dihasilkan dari keputusan yang disadari secara nyata, yang dapat dilihat sebagai hal rutin yang tidak secara aktif disengaja, bahkan bisa diperoleh secara historis dari keputusan di masa lalu (Leeuwis, 2009).

Sebagaimana halnya dengan petani pedesaan lain, peserta KUPS sebelumnya juga sudah memelihara sapi selain bertani. Namun demikian, pemeliharaan sapi yang dilakukan bertujuan untuk penggemukan, bukan untuk pembibitan. Dari pemeliharaan sapi berdasarkan pengalaman/kebiasaan yang sudah berlangsung lama, bukanlah jaminan untuk berhasil dalam usaha peternakan pembibitan sapi. Pemahaman ini yang perlu ditekankan pada semua elemen yang terlibat dalam pengelolaan program KUPS. Keberhasilan program KUPS didukung oleh ketepatan dan kelancaran penyaluran dan pengembalian kredit program, keberhasilan praktek budidaya pembibitan sapi oleh petani (yang berarti memerlukan dukungan teknis dan manajemen) serta evaluasi dan monitoring dalam implementasinya.

Pembibitan sapi potong merupakan usaha pemeliharaan ternak dengan tujuan untuk menghasilkan anak (Badan Penelitian dan Pengembangan Pertanian, 2010). Faktor penting dalam pembibitan sapi adalah faktor bibit/induk disamping manajemen pemeliharaan yang baik. Dalam program KUPS sapi yang dipakai sebagai bibit adalah sapi betina bunting/siap bunting, yang berasal dari sapi impor, sapi turunan impor dan sapi lokal. Pengadaan sapi impor dan turunannya untuk menambah populasi sapi, sedangkan sapi lokal untuk penyelamatan atau mengurangi pemotongan sapi betina produktif. Penggunaan sapi lokal dalam jumlah terbatas dan hanya pada wilayah sumber bibit sapi lokal dan diutamakan sapi Bali (Peraturan Menteri Pertanian, 2009).

Permasalahan pada pembibitan sapi potong yang sering dijumpai adalah menurunnya kesuburan atau berkurangnya fertilitas induk sapi yang ditandai dengan perkawinan lebih dari 3 kali tidak terjadi kebuntingan, birahi kembali terlambat (lebih dari 3 bulan setelah beranak), siklus birahi tidak teratur, tanda-tanda birahi secara berkala tidak tampak (birahi semu) serta keluar cairan tidak normal dari alat kelamin seperti darah atau nanah (Balai Pengkajian Teknologi Pertanian Jawa Tengah, 2010). Dengan demikian, kemampuan dalam pemilihan induk menjadi suatu keharusan apabila ingin mengembangkan bibit sapi secara baik.

Pada pelaksanaan KUPS di Kabupaten Sragen, kurangnya pemahaman peserta mengenai prosedur baku pelaksanaan pembibitan antara lain dilihat dari proses pemilihan induk sapi serta pemeliharaan dan pelaksanaan inseminasi buatan. Dalam proses pemilihan sapi induk, peserta mencari dan membeli sapi sendiri bersama kelompoknya ke pasar hewan di Sragen dan Ngawi. Harga induk sapi pada awal keikutsertaan mereka (tahun 2010) berkisar Rp 8 juta sampai Rp 9 juta; dengan jenis 
limousin dan simental. Untuk memilih induk yang menurut peserta berkualitas, didasarkan pada pengalaman mereka sebelumnya, antara lain dilihat dari ada tidaknya gigi yang tanggal dan jumlah garis pada tanduk. Menurut petani ternak informan, sapi mulai siap bunting pada umur 2 sampai 2,5 tahun. Sapi yang sudah bunting satu kali dicirikan dengan adanya gigi yang tanggal serta garis pada tanduk sudah kelihatan, tapi belum jelas. Pada sapi yang sudah bunting dua kali, terlihat jelas 1 buah garis pada tanduk.

Terkait dengan faktor bibit, perlu pemahaman fase reproduksi sapi betina dan proses reproduksi. Dalam manajemen pemeliharaan, peternak perlu melakukan pencatatan reproduksi berupa waktu birahi, tanggal/jam dikawinkan, berapa kali dikawinkan/IB, waktu mulai bunting, tanggal beranak, jumlah anak dan jenis kelamin, proses kelahiran, bunting kembali setelah melahirkan serta permasalahan penyakit selama proses kebuntingan serta biaya yang dikeluarkan.

Dari Tabel 1, persentase induk sapi yang berhasil bunting hanya 34\% dari keseluruhan induk sapi yang dibeli peserta. Hal ini bisa diakibatkan oleh kualitas induk yang dibeli peserta kurang bagus, pemeliharaan terutama asupan pakan yang kurang mendukung serta serta kurang tepatnya waktu mengawinkan sapi. Peserta seharusnya lebih memperhatikan pengaturan perkawinan dengan memperhatikan ketepatan waktu mengawinkan sapi birahi. Sebagai contoh, apabila waktu birahi pagi hari, saat terbaik mengawinkan adalah hari itu juga. Apabila waktu birahi sapi pada siang hari, waktu terbaik mengawinkan pada sore hari atau pagi hari berikutnya, sedangkan untuk waktu birahi sore hari, waktu tepat mengawinkan sapi adalah pada siang hari (Badan Penelitian dan Pengembangan Pertanian, 2010). Dari hasil wawancara, ada variasi kemampuan peternak mendeteksi waktu tepat untuk IB. Sebagai contoh kasus, begitu sapi ada tandatanda birahi (seperti: keluar lendir transparan atau agak mengental dari alat kelamin, sapi gelisah, vulva bengkak dan hangat dengan warna kemerahan, keluar air mata, tidak mau makan serta sering melenguh), banyak peserta yang langsung meminta inseminator untuk melakukan IB tanpa memperhatikan tenggang waktu birahi sampai saat tepat untuk IB.

Dari aspek kemitraan, implementasi aspek ini juga belum bisa dilaksanakan. Sesuai pedoman pelaksanaan KUPS, rekomendasi akan diberikan kepada pelaku usaha yang menyediakan sapi untuk usaha pembibitan sapi sesuai persyaratan prosedur baku dan melakukan kemitraan. Pola kemitraan bisa dalam 3 bentuk: 1) kemitraan antara perusahaan/koperasi dan kelompok/gabungan kelompok yang keduanya peserta KUPS; 2) kemitraan antara perusahaan/koperasi peserta KUPS yang memberikan gaduhan ternak sapi kepada kelompok/gabungan kelompok; serta 3) kemitraan antara kelompok gabungan/ gabungan kelompok peserta KUPS dengan perusahaan/koperasi sebagai penjamin (Dirjen Peternakan Departemen Pertanian, 2009). Hal ini sulit diterapkan, karena tidak adanya perusahaan pembibitan maupun koperasi yang bergerak di bidang pembibitan sapi yang bisa dijadikan mitra kelompok/gabungan peternak.

\section{Kendala dalam Implementasi KUPS}

Kredit produksi merupakan salah satu faktor pelancar pembangunan pertanian (Mosher, 1991). Guna membantu petani mengambil langkah ini, perlu dipermudah cara mendapatkannya dan diberi bimbingan mengenai cara menggunakannya. Ada beberapa masalah petani sehubungan dengan kredit produksi, yakni hal yang perlu diperhitungkan sebelum memutuskan mengambil kredit produksi: 1) menaksir besarnya hasil yang akan diperoleh; 2) menaksir berapa harga produk saat panen; 3) biaya kredit; 4) sanksi kalau tidak melunasi pinjaman; 5) kemudahan memperoleh kredit; serta 6) dapat meminjam tepat waktu.

Setiap petani mendasarkan tindakannya atas perhitungan biaya (cost) dan hasil 
(return). Ada diantaranya biaya dan hasil itu dinyatakan dalam bentuk uang (nilai), ada pula yang bersangkut-paut dengan kedudukan dan tanggung jawab petani dalam masyarakat. Perangsang produksi yang efektif bagi petani (dan berlaku pula bagi peserta program KUPS) terutama yang bersifat ekonomis, yakni: perbadingan harga yang menguntungkan, bagi hasil yang wajar serta tersedianya barang dan jasa yang ingin dibeli oleh petani untuk keluarganya (Mosher, 1991). Pengembangan teknologi pedesaan harus mengikuti tiga prinsip pokok agar dapat diterima masyarakat, yakni secara teknis dapat dilaksanakan, secara ekonomis menguntungkan dan secara sosial tidak menimbulkan kerawanan atau keretakan sosial (Levis, 1996).

Demikian halnya dengan program KUPS, penyerapan kredit program dan keberhasilan usaha yang dibiayai dari program ini, akan banyak dipengaruhi oleh persepsi peserta terhadap aspek ekonomis program KUPS, dengan tidak mengesampingkan aspek teknis dan sosial. Dari analisis hasil wawancara, kendala implementasi program KUPS untuk kelompok/gabungan kelompok peternak di Kabupaten Sragen dapat diuraikan dalam kerangka aspek teknis dan aspek ekonomis tersebut. Dari aspek teknis, kendala yang dihadapi adalah: 1) secara teknis dan manajemen kelompok/gabungan kelompok peternak peserta KUPS belum memiliki kemampuan yang memadai dalam usaha pembibitan sapi; 2) kurangnya infrastruktur pendukung yakni sulitnya mencari bibit sapi yang berkualitas; 3) tidak adanya perusahaan bibit sapi maupun koperasi yang bisa dijadikan mitra oleh kelompok ternak. Padahal mitra inilah yang memiliki kewajiban dalam membantu kelompok/ gabungan kelompok dalam pembinaan teknis dan manajemen, penyusunan rencana usaha pembibitan sapi dan pemasaran hasil produksi serta penyediaan sarana produksi peternakan yang diperlukan; 4) kurangnya pembinaan/pendampingan dari instansi terkait; 5) kurangnya monitoring pelak- sanaan sehingga beberapa persyaratan program tidak diterapkan (misalnya pemasangan microchip dan tidak ada kemitraan). Dari aspek ekonomi, kendala yang dihadapi terletak pada faktor: 1) fluktuasi harga pasar, dimana harga sapi menurun tajam dibandingkan dengan harga pembelian awal saat peserta memulai usaha, yang menyebabkan peserta mengalami kerugian karena tidak sebanding dengan biaya pemeliharaan yang sudah dikeluarkan; 2) kesulitan dalam membayar angsuran pokok maupun bunga kredit, karena jangka waktu kredit yang terlalu pendek (2 tahun) sedangkan usaha pembibitan belum bisa menghasilkan anak/pedet yang menguntungkan; 3) adanya resiko kegagalan IB serta resiko kematian sapi.

\section{KESIMPULAN DAN SARAN}

Implementasi program KUPS untuk kelompok/gabungan kelompok peternak belum bisa dilaksanakan secara optimal karena beberapa kendala yang bisa dikelompokkan dalam aspek teknis (kurangnya kemampuan teknis dan manajemen peserta KUPS dalam usaha pembibitan sapi, kualitas induk sapi yang kurang bagus karena ketiadaan mitra usaha) serta aspek ekonomi (resiko kegagalan inseminasi buatan dan kematian sapi/anak sapi, fluktuasi harga sapi, jangka waktu kredit terlalu pendek, yang kesemuanya berimbas pada kurangnya kemampuan membayar angsuran kredit). Dari kendala tersebut disarankan: 1) perlu adanya realisasi kemitraan dengan perusahaan bibit sapi yang bertanggung jawab dalam pendampingan teknis dan manajemen; 2) pemberian jangka waktu kredit lebih lama (3-4 tahun); 3) perlu asuransi kematian sapi yang dimasukkan dalam elemen kredit; 4) proses penetapan rekomendasi oleh dinas terkait dilaksanakan secara teliti dan bertanggung jawab; 5) keberpihakan perbankan dalam menetapkan jangka waktu kredit sesuai kondisi; 6) evaluasi dan monitoring program oleh stakeholder. 


\section{DAFTAR PUSTAKA}

Badan Penelitian dan Pengembangan Pertanian, 2010.Pedoman Teknis Budidaya Sapi Potong. Balai Pengkajian Teknologi Pertanian Jawa Tengah. Ungaran.

Chevny, Adam A, 2011. http://www.bisnisjatim.com/index.php/2011/11/21/penyerapa n-kredit-usaha-pembibitan-sapi-minim/

Dinas Peternakan dan Perikanan Kabupaten Sragen, 2012. Laporan Realisasi KUPS Tahun 2010 Kabupaten Sragen. Sragen.

Dinas Peternakan dan Perikanan Kabupaten Sragen, 2012. Laporan Tahunan Dinas Peternakan dan Perikanan Kabupaten Sragen 2011. Sragen

Direktorat Jenderal Peternakan Departemen Pertanian, 2009. Pedoman Pelaksanaan Kredit Usaha Pembibitan Sapi (KUPS). Jakarta

Direktorat Jenderal Peternakan Departemen
Pertanian, 2010. Surat Edaran Nomor : 12020/SE/KU.340/F/03/2010 Tentang Kebijakan Penggunaan dan Pemanfaatan Microchip untuk Identifikasi Sapi Kredit Usaha Pembibitan Sapi (KUPS). Jakarta

Leeuwis, C. 2006. Komunikasi untuk Inovasi Pedesaan. Berpikir Kembali tentang Penyuluhan Pertanian. Terjemahan oleh B. E. Sumarah. Kanisius. Yogyakarta.

Levis, L,R., 1996. Komunikasi Penyuluhan Pedesaan. Citra Aditya Bakti. Bandung.

Mosher, A.T, 1991. Menggerakkan dan Membangun Pertanian. Syarat-syarat Pokok Pembangunan dan Modernisasi. CV Yasaguna. Jakarta.

Rogers, E. M. 2003. Diffusion of Innovations. Fifth Edition. Free Press. New York

Sutopo, H.B. 2006. Metodologi Penelitian Kualitatif. Dasar teori dan terapannya dalam penelitian. Edisi 2. Universitas Sebelas Maret. Surakarta 